\title{
ANALYSIS OF THE INFLUENCE OF 3D PRINTING ON HARDNESS OF PARTS
}

\author{
Tomislav Pavlic, Ante Čikić, Stjepan Golubić
}

Original scientific paper The principles of additive production are such that they enable the making of very complex product geometry. The hardness of printed parts is not increased proportionally to the increase of the infill of the parts themselves. Different ways of printing have a bigger impact on the hardness than the infill. The research conducted on the "solid" model samples established sufficient hardness of parts gained from 3D printing with less material use and shorter time of production due to correct selection of parameters and the way of printing.

Keywords: 3D print; ABS; deflection; infill

\section{Analiza utjecaja načina 3D printanja na krutost dijelova}

Izvorni znanstveni članak

Načela aditivne proizvodnje su takva da omogućuju izradu vrlo komplicirane geometrije proizvoda. Krutost printanih dijelova ne raste proporcionalno povećanju ispuna samih dijelova. Načini printanja imaju veći utjecaj na krutost od same ispune. Provedenim ispitivanjima na uzorcima "punog" modela utvrđena je zadovoljavajuća krutost dijelova dobivenih 3D printanjem uz manje utrošenog materijala i kraće vrijeme izrade pravilnim izborom parametara i načina printanja.

Ključne riječi: ABS; ispuna; progib; $3 D$ print

\section{Introduction}

Contemporary market demands impose strict conditions on the processes related to development and production. Besides demands regarding product quality and flexibility level, the market simultaneously imposes requests for reduction of costs and especially for reducing the time for development and production [1]. Emergence of 3D printers has facilitated the manufacture of complex geometries to numerous users unable to develop them using some other technologies. Improved possibilities of 3D printing will contribute to faster development of technological procedures in the future $[2,6,7]$. Due to lack of confirmed research regarding the characteristics of behaviour of materials used in 3D printing by means of using the equipment, according to $[3 \div 5]$ it is not possible to adequately assess the "solid" model with reference to the "hollow" one. "Solid" models are more expensive to make, they require more material, the printing lasts longer and they have bigger mass, whereas "hollow" models are used for models which are not completely filled with material and have more complex construction requirements. The emphasis is placed on visuality, which contributes to qualitative integrity of the product. Simplified computer programmes adapted to 3D printing enable relatively quick comprehension of $3 \mathrm{D}$ printing with the infill ways of printing (Horizontal / Vertical), layer height (Layer Height), model shell (Shell) etc. In a few steps and adjusted parameters it is possible to carry out a $3 \mathrm{D}$ print of a certain model.

\section{Method}

Subject matter of this analysis is construction variants of products made by means of using 3D printers of low total costs [3]. Compared to the price of material, the influence of device price is significantly lower in total costs of production of parts $[3,4]$. Used FDM technology of $3 \mathrm{D}$ printing, is described in $[10,11]$. The samples on which measurements were made are the same shape as the sample described in [9].

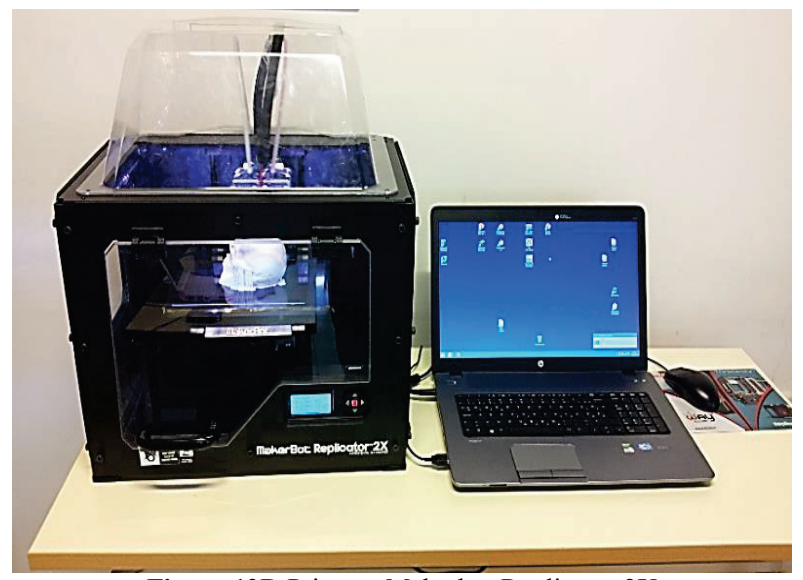

Figure 13D Printer - Makerbot Replicator 2X
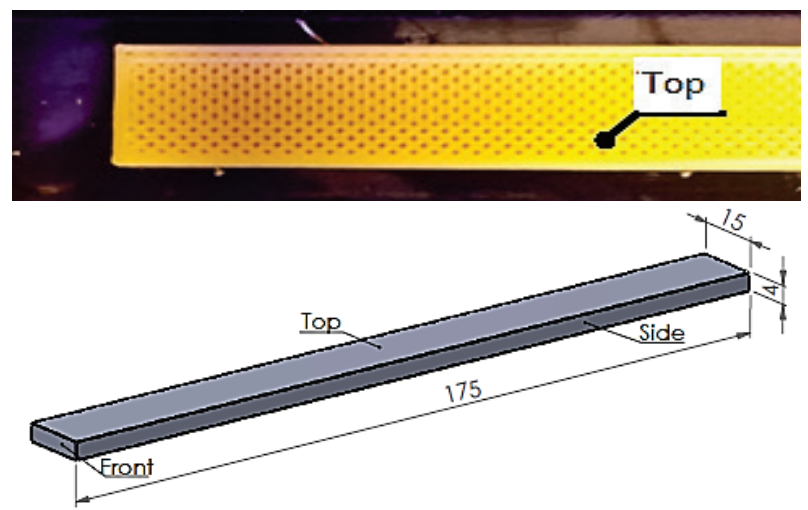

Figure 2 3D printed test sample and side naming

In order to obtain satisfactory construction solutions for the needs of small series production by means of using 3D print (in this case ABS, wire diameter $1,75 \mathrm{~mm}$ ), rational selection of model infill combinations (Infill), ways of print (Horizontal / Vertical) [8], layer height 
(Layer Height), model shells (Shell) etc. can result in significant reduction of costs.

Tab. 1 provides an outline of basic settings in usage of $3 \mathrm{D}$ printers.

Table 1 Parameters of 3D printed samples

\begin{tabular}{|c|c|c|c|c|c|c|c|c|}
\hline \multirow{2}{*}{ Parameters } & \multicolumn{7}{|c|}{ Number of samples } \\
\cline { 2 - 10 } & 1 & 2 & 3 & 4 & 5 & 6 & 7 & 8 \\
\hline Infill / \% & 25 & 50 & 75 & 100 & 25 & 50 & 75 & 100 \\
\hline Number of shells & 2 & 2 & 2 & 2 & 2 & 2 & 2 & 2 \\
\hline Layer height / mm & 0,3 & 0,3 & 0,3 & 0,3 & 0,3 & 0,3 & 0,3 & 0,3 \\
\hline $\begin{array}{c}\text { Extruding traveling } \\
\text { speed / mm/s }\end{array}$ & $120 /$ & $120 /$ & $120 /$ & $120 /$ & $120 /$ & $120 /$ & $120 /$ & $120 /$ \\
150 & 150 & 150 & 150 & 150 & 150 & 150 & 150 \\
\hline $\begin{array}{c}\text { Horizontal/Vertical } \\
\text { print }\end{array}$ & Hor. & Hor. & Hor. & Hor. & Ver. & Ver. & Ver. & Ver. \\
\hline
\end{tabular}

Prior to production of samples, Fig. 2, 3D printer is calibrated according to the instructions of the manufacturer [3]. The samples were made by using a version of the software programme MakerWare 2.4.0.14, with 3D printer MakerBot Replicator 2X V7.5 drivers [3].

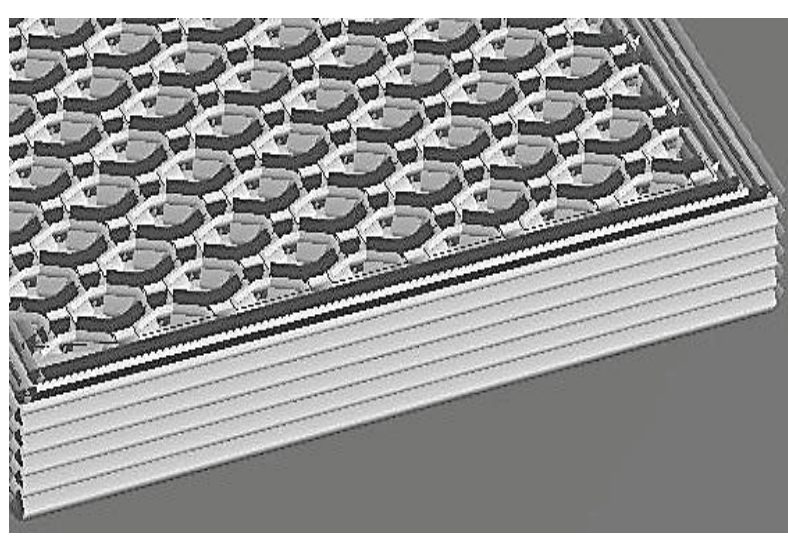

Figure 3 Toolpath Visualization of sample $175 \times 15 \times 4 \mathrm{~mm}$ (Horizontal print- Infill $75 \%$ )

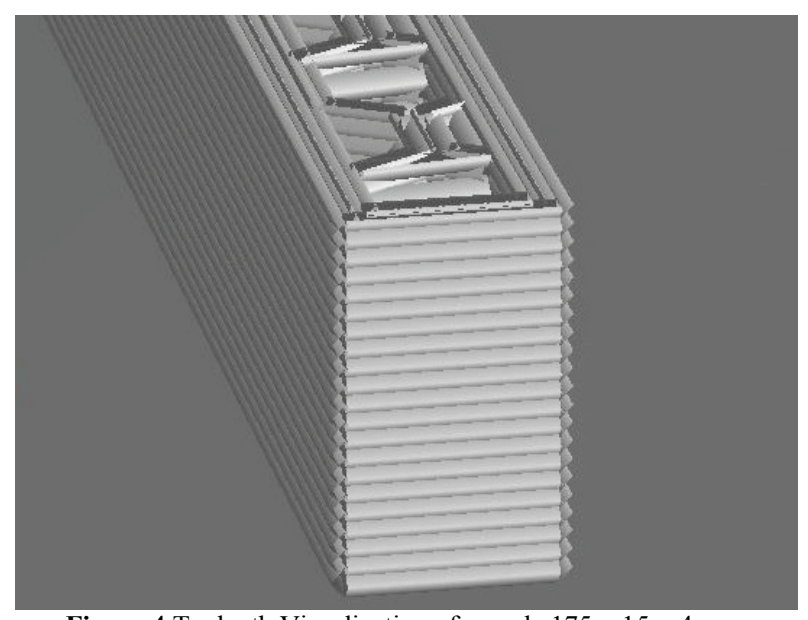

Figure 4 Toolpath Visualization of sample $175 \times 15 \times 4 \mathrm{~mm}$ (Vertical print- Infill $25 \%$ )

Print time and quantity of material used, Figs. 3 and 4 , vary according to the infills of the used samples [4].

Side 1 of the sample is always the one laying on the build plate, and side 2 is for all samples always the final layer, Fig. 5. Performance of a 3D printer is such that the build plate, on which the part being printed is located, is heated to $130{ }^{\circ} \mathrm{C}$, and during testing it influences the sample quality.

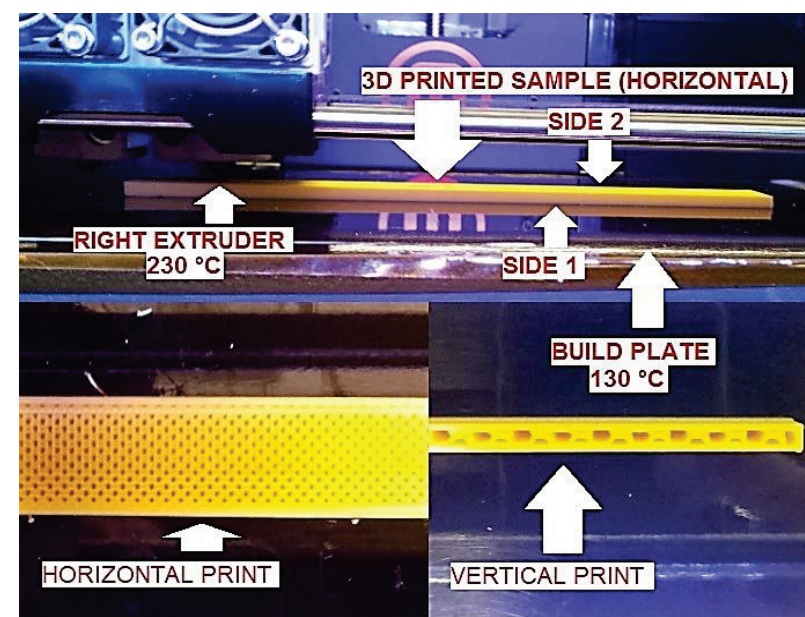

Figure 5 Test sample, side naming, type of 3D printing, description of $3 \mathrm{D}$ printer

\section{Results}

Samples on which research was conducted differ according to print direction, horizontally, vertically, as well as whether they were turned to side 1 or side 2 during measuring of deflection, and subsequently according to the percentage of the infill within the sample, Fig. 5. In the process of measuring the deflection we used equipment shown in Fig. 6. Precision weights were used which correspond to forces from $0,981 \mathrm{~N}$ and 1,962 N. To measure the deflection a comparator was used.

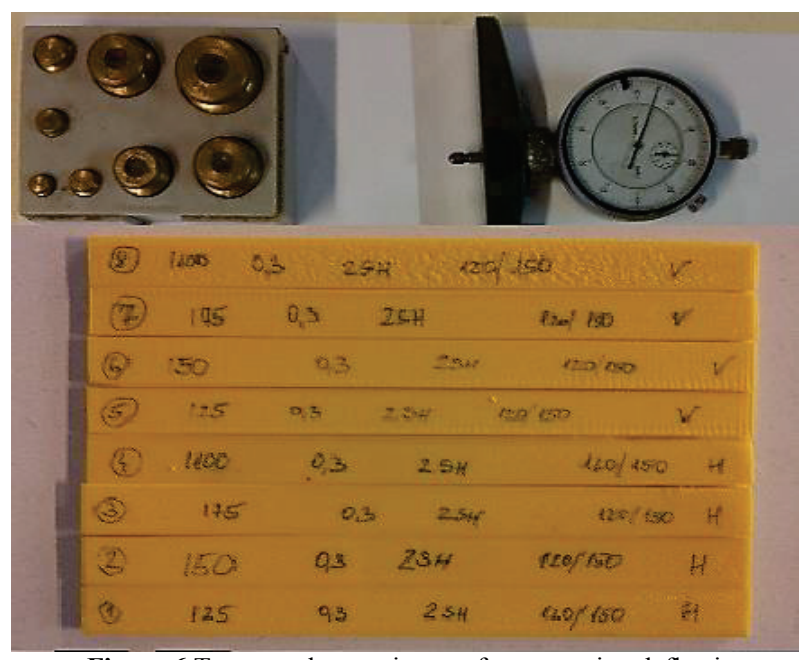

Figure 6 Test samples, equipment for measuring deflection

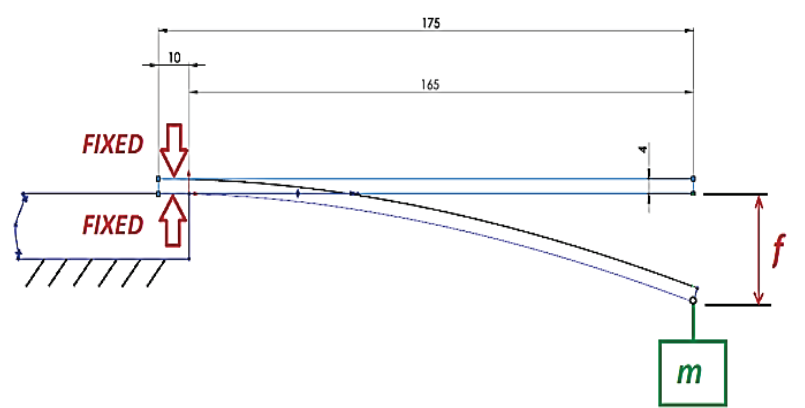

Figure 7 Method of measuring deflection

Method for measuring the deflection is illustrated in Fig. 7, and the results of measurements of deflection are presented graphically below. 


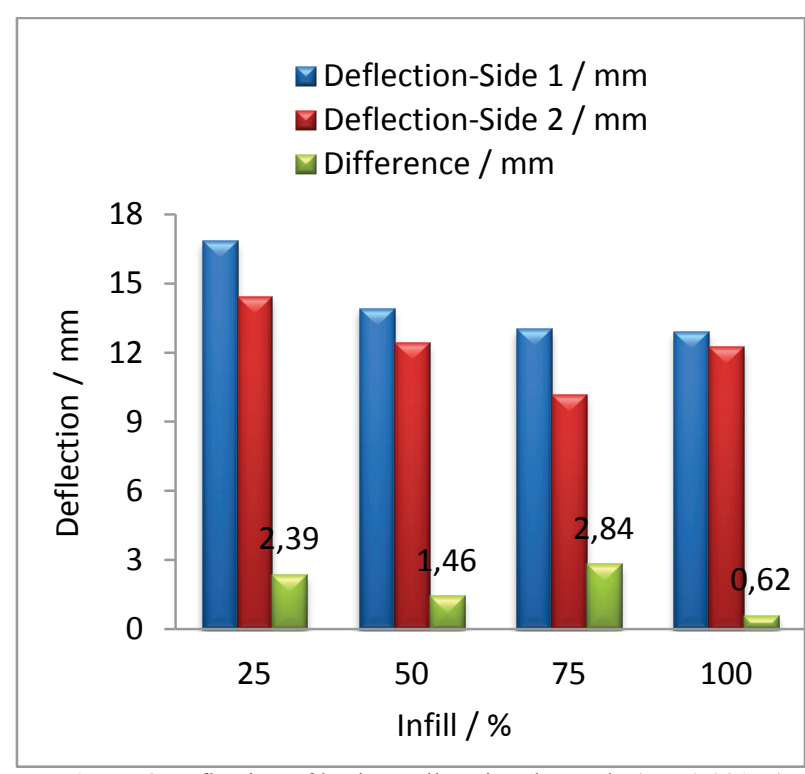

Figure 8 Deflection of horizontally printed sample $(F=0,981 \mathrm{~N})$

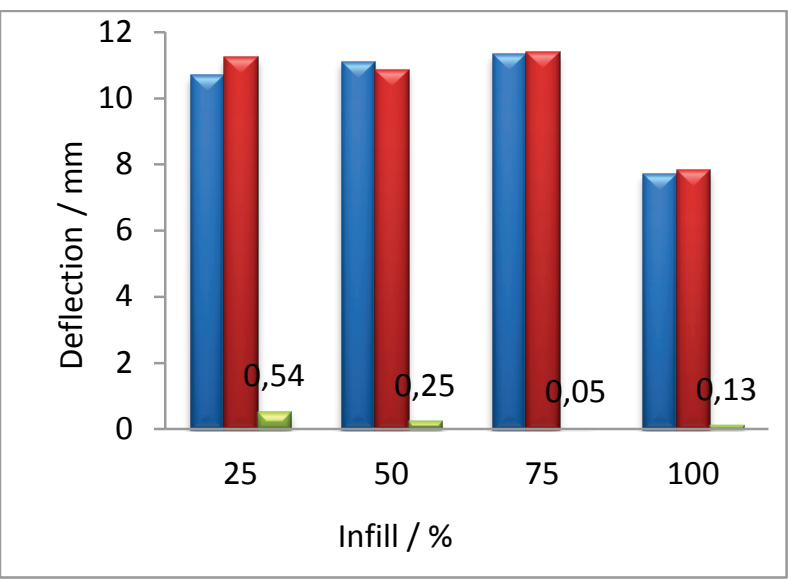

Figure 9 Deflection of vertically printed sample $(F=0,981 \mathrm{~N})$

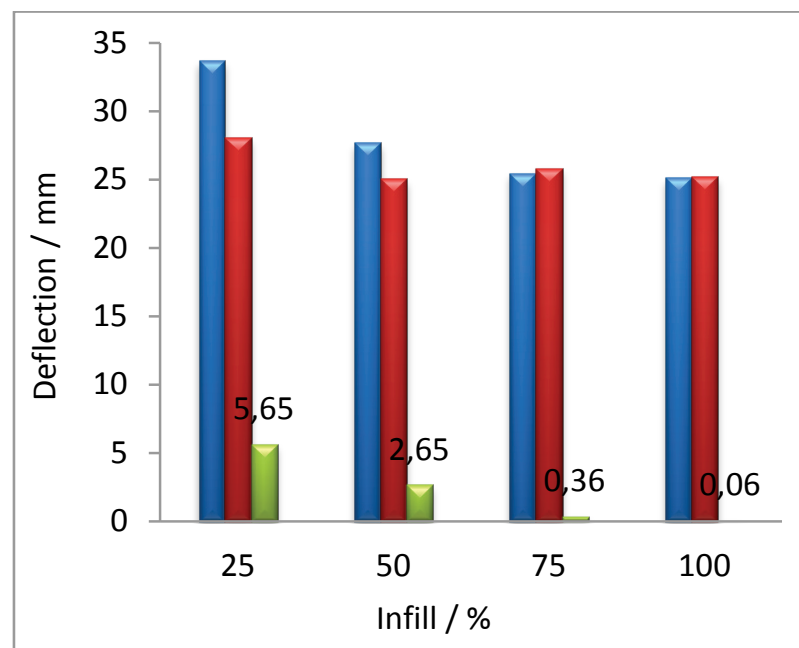

Figure 10 Deflection of horizontally printed sample $(F=1,962 \mathrm{~N})$

Assessment of deflection indicated significant differences outlined in charts in Figs. $8 \div 11$. Computer simulation of deflection assessment for loads of $0,981 \mathrm{~N}$ and 1,962 $\mathrm{N}$ was made for the sample used in testing, whose dimensions were $175 \times 15 \times 4 \mathrm{~mm}$, Fig. 12 . The length of the side exposed to force was $165 \mathrm{~mm}$. The sample was fixtured on the length of $10 \mathrm{~mm}$, Fig. 12 . Programming tool Solidworks, module Simulation was used. Fixture and load of sample sized $175 \times 15 \times 4 \mathrm{~mm}$ are depicted in Fig. 12.

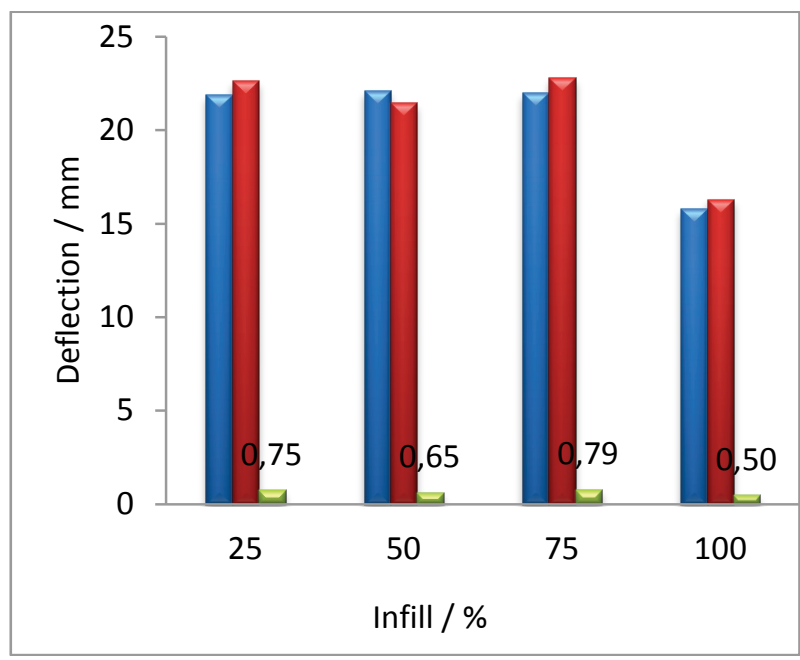

Figure 11 Deflection of vertically printed sample $(F=1,962 \mathrm{~N})$

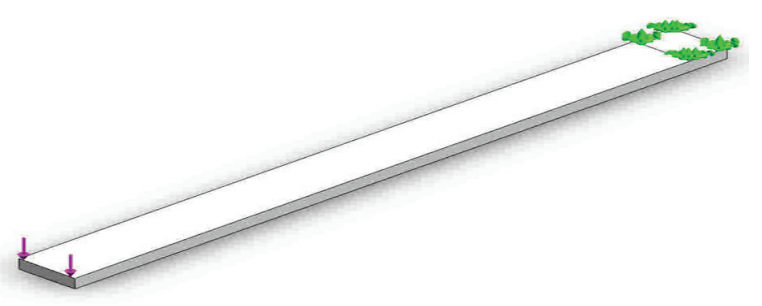

Figure 12 Fixture and Load-sample $175 \times 15 \times 4 \mathrm{~mm}$

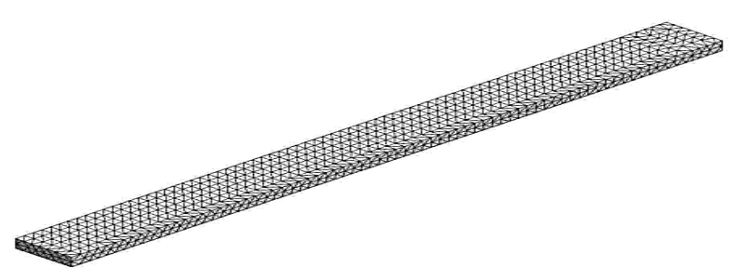

Figure 13 Mesh - sample $175 \times 15 \times 4 \mathrm{~mm}$

Table 2 Material Properties - SW Simulation

\begin{tabular}{|l|l|}
\hline Name: & ABS \\
\hline Model type: & Linear Elastic Isotropic \\
\hline Tensile strength: & $30 \mathrm{MPa}$ \\
\hline Elastic modulus: & $2 \times 10^{3} \mathrm{MPa}$ \\
\hline Poisson's ratio: & 0,394 \\
\hline Mass density: & $1020 \mathrm{~kg} / \mathrm{m}^{3}$ \\
\hline Shear modulus: & $0,319 \times 10^{3} \mathrm{MPa}$ \\
\hline
\end{tabular}

\begin{tabular}{|l|l|}
\multicolumn{2}{c}{ Table 3 Mesh Information - SW Simulation } \\
\hline Mesh type & Solid Mesh 2 \\
\hline Mesher used & Standard mesh \\
\hline Element size & $2,3597 \mathrm{~mm}$ \\
\hline Mesh quality & High \\
\hline Total nodes & 11075 \\
\hline Total elements & 6352 \\
\hline Time to complete mesh (hh:mm:ss) & $00: 00: 03$ \\
\hline
\end{tabular}

Properties of material used for simulations are defined in programming tool SolidWorks, and are located in the library of the module Simulation, and displayed in Tab. 2.

Properties of final elements of the mesh are displayed Tab. 3. 
Response results of computer simulation of deflection assessment for load force of $0,981 \mathrm{~N}$ are displayed in Fig. 14, whereas Fig. 15 displays response results of computer simulation of deflection assessment for load force of $1,962 \mathrm{~N}$.

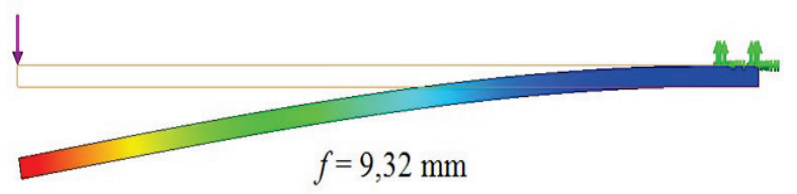

Figure 14 Simulation assessment of sample deflection loaded with mass of $0,1 \mathrm{~kg}$ (corresponds to 3D printed sample with $100 \%$ infill)

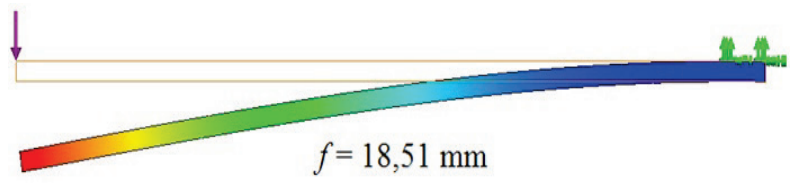

Figure 15 Simulation assessment of sample deflection loaded with mass of $0,2 \mathrm{~kg}$ (corresponds to 3D printed sample with $100 \%$ infill)

By means of using computer numeric simulations it was established that double load results in approximately twice as large deflection of the tested sample, Figs. 14, 15. Sample dimensions displayed in Figs. 2, 7, 12 were used for analytic calculation of deflection.

$$
\begin{aligned}
& f=\frac{F \cdot l^{3}}{3 E I}, \\
& I=\frac{b \cdot h^{3}}{12} .
\end{aligned}
$$

In formula (1) the following sizes were used for analytic calculation of deflection: $f$ - deflection (mm), $F$ force loading the sample $(\mathrm{N}), l$ - the side exposed to the force $F(\mathrm{~mm}), E$ - Young's module of elasticity (MPa), $I$ moment of inertia of the console cross-section $\left(\mathrm{mm}^{4}\right)$, whereas (2) $b$ and $h$ represent dimensions of sample cross-sections (mm). Response results of computer simulation of deflection assessment for load force of $0,981 \mathrm{~N}$ and $1,962 \mathrm{~N}$, amount to $9,32 \mathrm{~mm}$ and $18,51 \mathrm{~mm}$, whereas according to analytic calculations deflection values amount to $9,18 \mathrm{~mm}$ for the force of $0,981 \mathrm{~N}$, and $18,36 \mathrm{~mm}$ for the force of $1,962 \mathrm{~N}$.

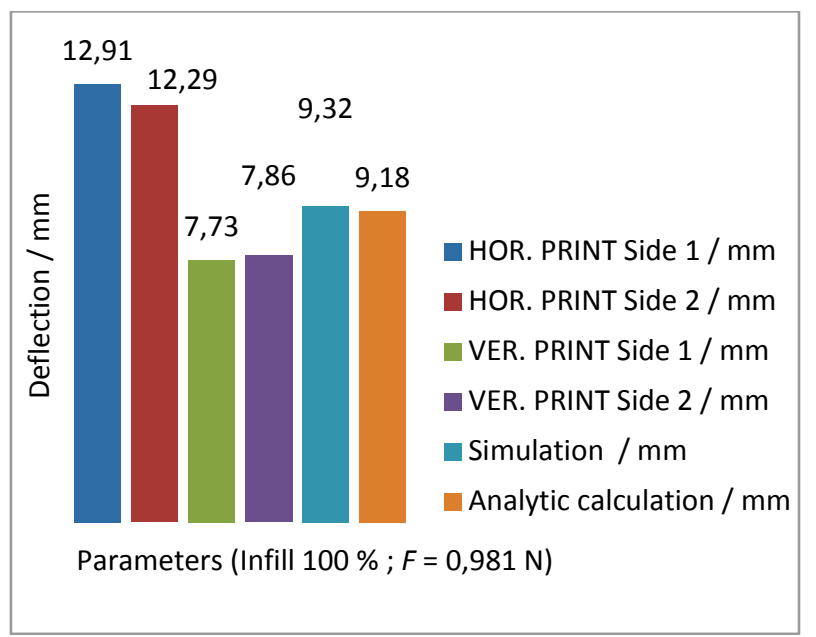

Figure 16 Comparison of experimentally established deflections of printed samples with the simulation and analytic calculation $(F=0,981 \mathrm{~N})$

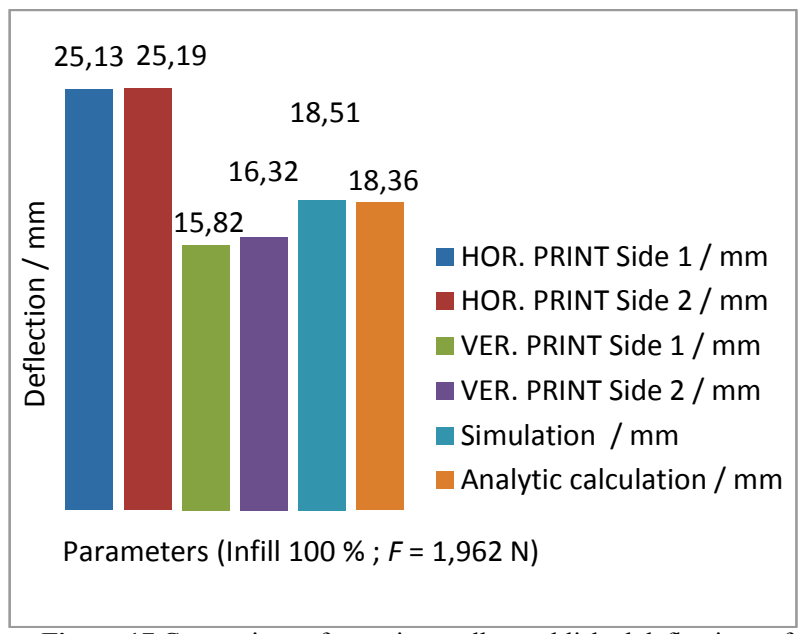

Figure 17 Comparison of experimentally established deflections of printed samples with the simulation and analytic calculation $(F=1,962 \mathrm{~N})$

\section{Discussion}

Conducted research established small discrepancies of deflection values of the tested samples between computer simulations and analytic calculations for the "solid" model (Figs. 16, 17). Significant differences were observed with experimental testing related to different ways of 3D printing (horizontally, vertically, side 1 , side 2 ), with reference to analytic calculation and simulation.

\section{Conclusion}

Lack of knowledge related to accurate characteristics of the used ABS filament (cheap material and 3D printer) influences the values observed with different procedures. Print direction (horizontally, vertically) has a bigger influence on sample hardness than the infill of the model. Analytic calculations and computer simulations indicated small discrepancies of deflection values of tested sample related to the "solid" model.

\section{References}

[1] Šercer, M.; Godec, D.; Pilipović, A. Additive Technologies for the SMEs, 2014.

[2] Liou, F. W. Rapid Prototyping and Engineering applications: A Toolbox for Prototype Development, 2008.

[3] http://downloads.makerbot.com/replicator2x/MakerBot_ Replicator_2X_User_Manual.pdf

[4] http://store.makerbot.com/plastic/1-5mm-filament

[5] http://download.makerbot.com/filament/ABS_MSDS_ MakerBot_Stratasys.pdf

[6] http://hbr.org/2013/03/3-d-printing-will-change-theworld/ar/ 1

[7] Guo, N.; Ming, C. Additive manufacturing: technology, applications and research needs. // Front. Mech. Eng. 8, 3(2013), pp. 215-243. DOI: 10.1007/s11465-013-0248-8

[8] Pilipović, A.; Raos, P.; Šercer, M. Experimental testing of quality of polymer parts produced by laminated object manufacturing. // Technical Gazette. 18, 2(2011), pp. 253260.

[9] Wenzheng, W.; Peng, G.; Guiwei, L.; Di, Z.; Haibo, Z.; Ji, $Z$. Influence of Layer Thickness and Raster Angle on the Mechanical Properties of 3D-Printed PEEK and a Comparative Mechanical Study between PEEK and ABS. // 
Materials. $\quad 8, \quad$ (2015), pp. 5834-5846. DOl: 10.3390/ma8095271

[10] Pilipović, A.; Šercer, M.; Valentan, B. Use of low-cost 3D printers and the influence of parameters on the precision and mechanical properties, CIM 2011, Biograd na moru, pp. 187-194.

[11] Surma, R.; Šercer, M.; Pilipović, A. Designing and production of polymer product with Fused deposition modeling - case study, CIM 2015, Vodice, pp. 221-226.

\section{Authors' addresses}

Tomislav Pavlic, M.M.E.

Technical college in Bjelovar

Trg Eugena Kvaternika 4, 43000 Bjelovar, Croatia

E-mail: tpavlic@vtsbj.hr

Ante Čikić, Assoc. Prof. PhD

Technical college in Bjelovar

Trg Eugena Kvaternika 4, 43000 Bjelovar, Croatia

E-mail: acikic@vtsbj.hr

Stjepan Golubić, M.Sc

Technical college in Bjelovar

Trg Eugena Kvaternika 4, 43000 Bjelovar, Croatia

E-mail: sgolubic@vtsbj.hr 